\title{
PERGESERAN PEMIKIRAN KALAM TRADISIONAL KE KONTEMPORER (Kajian Metodologi Kalam Klasik dan Kalam Sosial)
}

\author{
Ahmad Muhtarom \\ Sekolah Tinggi Agama Islam Nahdlatul Ulama Jakarta \\ Ahmadmuhtarom90@gmail.com
}

\begin{abstract}
Abstrak
Bangunan epistemologi dan metodologi dalam kalam klasik cenderung bersifat skriptualis dan anatomistik, yang tidak mengindahkan kehidupan nyata. Hal ini menjadi tantangan tersendiri dalam menjawab berbagai tantangan keilmuan yang kian modern. Sedangkan pembahasan kalam kontemporer tidak selalu sama dengan wacana yang ditelurkan kalam klasik namun harus ada penambahan, perluasan objek kajian, progresifitas berpikir, inovasi, rekonstruksi, dialogisasi, integrasi yang semuanya menunjukkan akan pentingnya pergeseran paradigma yang lebih membumi dan dapat menyesuaikan dengan disiplin keilmuan profan lainnya tanpa ada sikap tabu, alergi dan antipati terhadap disiplin keilmuan di luar diri (eksternal) kajian kalam klasik.
\end{abstract}

Kata kunci: Metodologi, Kalam, Klasik, Kontemporer.

\begin{abstract}
Abstact
The Building of epitemology and metodologi in clasical kalam tends to scriptive and anatomistive, it means that it doesn't reveal the real lives. so have is a challenge in answering all questions that come from the new an so sophisticated knowledges. While in contemporer there is no description leveled by the classical. The contemporer has added the objects, thinking, innovation, reconstruction, dialogue in the progress, and it can show the importance of the exchange rally, and it can also as diciplin as other knowledgement without taboo, allergic an so on.
\end{abstract}

Keyword: Methodology, Classical, Contemporer, Kalam 


\section{A. Pendahuluan}

Islam merupakan agama samawi yang diturunkan Allah kepada manusia di dunia yang berfungsi sebagai petunjuk ( $h u d \bar{a})$ untuk dapat membedakan perbuatan yang baik dan buruk dan perbuatan yang bermanfaat dan mudarat. Ajaran yang terkandung di dalam al-Qur'an mengandung tiga aspek pokok yaitu akidah, ibadah, dan muamalah. Ketiga aspek tersebut mempunyai peranan, signifikansi, dan ajarannya tersendiri sekaligus mandiri (mustaqil) namun memiliki hubungan erat antara satu dengan yang lain. Dalam artian bahwa ketiga aspek Islam tersebut harus berjalan sinergi dan harmonis sekaligus tidak mengandung unsur pertentangan (ta'āruḍ) di dalamnya. ${ }^{1}$ Aspek akidah merupakan substansi keberagamaan umat manusia yang menjadi pilar Islam yang harus diyakini dan diterima secara pasti sebagai suatu doktrin yang bersifat transendental dari Tuhan semesta alam. Aspek ibadah merupakan bukti konkret dari perintah menjalankan aspek normatif yang ditentukan Allah di dalam al-Qur'an dan Sunnah Rasul Saw. sebagai sarana pendekatan diri (taqarrub), pensucian jiwa (tazkiyah al-nafs) yang dibalut dalam usaha-usaha spiritual (riyāglah) kepada Allah. Sedangkan aspek muamalah merupakan aspek sosial kemasyarakatan dalam hubungan horisontal antar sesama manusia yang menitikberatkan pada hubungan antar sesama manusia (al-ukhuwah al-insāniyyah), hubungan antar sesama umat Islam (al-ukhuwah al-islämiyyah) maupun hubungan antara manusia dan tanah airnya (al-ukhuwah alwațāniyyah).

Namun dari ketiga aspek di atas, aspek akidah atau tauhid merupakan aspek paling urgen. Urgensitasnya terletak pada kandungan (madmīn/content) yang terdapat di dalamnya yaitu tentang pengakuan akan keesaan Allah secara murni dan konsekuen tanpa ada rasa ragu (syak) dan bimbang. Semakin kuat aspek ini tertanam dalam setiap individu akan berimplikasi pada kuatnya aspek lain (ibadah dan muamalah), dan sebaliknya, semakin lemah aspek ini akan berimplikasi pada hancurnya aspek lain. Hal ini yang menjadikan aspek akidah sebagai prinsip radikal dan substansial dari

\footnotetext{
${ }^{1}$ Maḥmūd Syaltūt, al-Islām Wa al-Syarī'ah (Kairo: Dār al-Qalam, 1966), h. $11-3$.
} 
berbagai aspek kehidupan manusia di dunia. Maka tidak mengherankan jika pembahasan yang paling sering diulas dan dibahas - sekaligus menjadi suatu yang niscaya - oleh para ulama (al-salaf alșăliḥūn) adalah persoalan bagaimana memperkenalkan Allah sebagai pencipta alam semesta yang memiliki sifat dan kekuasaan yang mutlak. Pembahasan ini tentu saja diterangkan dalam ilmu akidah yang menjadi keniscayaan bagi setiap individu untuk mengetahuinya. Dalam sebuah adagium klasik dikatakan 'awwalu wājibin 'alā almukallaf ma 'rifat ilāh bi istițā' $i$ (persoalan pertama yang wajib bagi mukalaf adalah mengetahui akan eksistensi Tuhan dengan daya kemampuannya). Yang dimaksud dengan persoalan pertama yang wajib adalah persoalan yang ada kaitannya dengan urusan agama yang itu merupakan suatu keharusan (al-umūr al-darūriyyah fì al-dīn) yang tidak boleh ditinggalkan dan dilupakan. Dengan adanya penetapan (taqrīr) di atas sekaligus menjadi justifikasi bahwa aspek akidah merupakan aspek prinsipiil bagi agama Islam yang tidak boleh tidak harus diimani, diyakini, dan menjadi pandangan hidup (view of life) bagi setiap individu.

Konsep akidah yang komprehensif tertera di dalam al-Qur'an surat al-Ikhlāṣ [112] ayat 1-5., yang mengandung unsur pokok dalam keimanan yaitu Zat yang disembah (Allah) adalah esa (ahad) yang tidak memiliki sekutu (lā syarīka lah) dan perumpamaan (lā syabīha lah wa là nazīra) baik di dalam zat, sifat maupun perbuatan-Nya. ${ }^{2}$ Konsep ini tentu berbeda secara diametral dengan konsep trinitas (altatslīts) dalam agama Nasrani yang mengandung doktrin adanya tiga oknum dalam Zat Tuhan yaitu 'Bapak, Anak dan Rūḥ Kudus'. Adapun konsep akidah atau tauhid yang ditawarkan Islam terbebas dari asumsi ada Zat lain yang berdiri sendiri di luar diri-Nya, karena Allah adalah Zat Yang Esa dan tidak ada sekutu bagi-Nya. Perkataan esa/satu (ahad $)^{3}$ tidak mengandung dan tidak boleh dipahami dalam

2 'Alī al-Ṣābūnī, Ṣafwat al-Tafāsīr (Kairo: Dār al- Șābūnī, 1997), h. 594.

${ }^{3}$ Menurut ahli bahasa, kata ahad sinonim dengan wāhid yang berarti satu. Seperti dalam ucapan satu (ahad), dua (itsnān), .. sebelas (ahada 'asyara atau iḥdā 'asyrah). Adapun kata aḥad yang terdapat di dalam surat al-Ikhlāṣ tidak mempunyai persamaan bilangan tetapi sinonim dengan fard (esa, tunggal) yang berarti senantiasa sendiri dan tidak ada yang lain selainnya. Seperti ucapan lā ahad fí al-dār (di rumah tidak ada orang), sehingga tidak boleh diucapkan di rumah ada orang. Muḥammad bin Mukrim bin Manẓūr, Lisān al- 'Arab (Beirut: Dār al-Ṣādir, t.tn), Jld. 
pengertian jumlah ( 'adad) di mana satu merupakan setengah dari dua, sepertiga dari tiga dan seterusnya yang secara ad infinitum (terus menerus) akan berimplikasi pada mengatakan bahwa Allah itu banyak dan tidak tunggal dalam realitas-Nya. Akan tetapi kata esa/satu (ahad) dipahami dalam pengertian bahwa Allah; tidak ada sesuatu yang menyekutukan-Nya, tidak ada sesuatu yang setara dengan-Nya, dan tidak ada sesuatu yang semisal dengan-Nya baik di dalam zat, sifat maupun perbuatanNya. ${ }^{4}$

\section{B. Dialektika Pemikiran Kalam Awal dalam Islam}

Pemahaman akidah umat Islam-dalam pemikiran yang paling awal, sekitar abad I H., sangat sederhana dan menjauhi hal-hal yang bersifat dialektis. Pada umumnya umat Islam mengonsepsikan Tuhan sebagai sesuatu yang memiliki eksistensi mutlak (wujūd). Tuhan itu Ada dengan sendiri-Nya dan sesuatu selain diri-Nya dinamakan 'àlam yang diciptakan oleh Tuhan. Artinya bahwa konsepsi tentang Tuhan hanya berkisar antara wujūd (yang Ada) dan maujūd (yang diadakan). Segala atribut (sifat) dan kekuasaan (qudrah) Tuhan tidak dipersoalkan karena menjadi hal yang 'tabu' untuk diperbincangkan dan tidak ada ruang kosong untuk mendiskusikan, mendialogkan, dan mempersoalkannya. Pembahasan dan pengajaran akidah yang sederhana tersebut sangat komprehensif pada zaman itu mengingat konsep awal dalam Islam dalam hal akidah adalah pengenalan akan Zat Allah Yang Maha Esa, tidak ada sekutu (lā syarīka lah) dan permisalan (lā syabīha lah) sekaligus mencounter pendapat zaman jahiliyah yang mempercayai banyak sesembahan (așnām) dan pendapat kaum Nasrani yang berpaham trinitas (al-tatslìts). Islam datang hendak merekonstruksi berbagai paham yang tidak sesuai dengan nilai-nilai ajaran yang hanīf (suci) yaitu hanya mempercayai akan satu sesembahan (monoteisme). Paham monoteisme inilah yang sesungguhnya menjadi misi utama diturunkannya Islam kepada

3, h. 70., Ibrāhim Anīs, dkk, al-Mu 'jam al-Wasīt (Kairo: Majma‘ al-Lughah al'Arabiyyah, t.tn), h. 28., Muḥammad bin Abī Bakr al-Rāzī, Mukhtār al-Ṣiḥ̣āh (Beirut: Dār al-Fikr, 2009), h. 13.

4 'Alī Sāmī al-Nasysyār, Nasy'at al-Fikr al-Falsafì (Kairo: Dār al-Ma‘ārif, 1977), Jld. 1, h. 235. 
bangsa Arab - secara khusus dan kepada seluruh umat manusia pada umumnya - yang masih berpaham politeisme.

Prinsip monoteisme -dengan segala pembahasan yang sederhana seputar Zat Tuhan- tetap dipertahankan sampai Nabi Muhammad Saw. wafat (632 M.) dan tidak ada seorangpun yang mencoba lari dan keluar dari arus mainstream karena ada larangan dari Nabi Saw. tentang mempertanyakan Zat Tuhan lebih jauh, terperinci (tafșill), dan bersifat partikular (juz'iyyāt) sebagaimana sabdanya 'tafakkarū fì khalq Allāh walā tafakkarū fì dzātih'.5 Ada larangan secara eksplisit tentang berspekulasi akan dzat Allah menjadikan mayoritas umat Islam stagnan dalam ranah akidah. Ranah akidah merupakan kawasan transendental yang suci dari segala prasangka dan hal yang bersifat spekulatif lainnya karena pada ranah ini kemampuan akal manusia dalam melakukan eksplorasi intelektual ditekan dan dikungkung sekuat mungkin supaya tidak bisa keluar dari koridor-koridor yang telah ditentukan oleh teks-teks keagamaan (alnușuṣ aldīniyyah) yang rigid. Ketidakmungkinan membahas tentang dzat dan sifat Allah secara terperinci didukung pula kondosi sosial yang tidak kondisif karena semua perhatian dicurahkan dalam masalah menghafal al-Qur'an dan hadis dan proses kodifikasi. Maka katarteristik pemikiran akidah atau kalam dalam kurun abad pertama hijriyah bersifat dogmatis-stagnan karena diskursus atau wacana ketuhanan hanya berkutat pada masalah wujūd (yang Ada) dan maujūd (yang diadakan).

Permasalahan kalam mendapatkan momentum, sekaligus akan bersifat lebih kompleks, ketika terjadi peristiwa arbitrase (tahkim) yang melibatkan terjadi perpecahan politik antara dua kalangan elit umat Islam yaitu antara 'Alī bin Ab̄i Țālib vis a vis $\mathrm{Mu}$ 'āwiyah bin Abī Sufyān yang berimplikasi munculnya berbagai kelompok seperti Khawārij (kelompok yang keluar dari dua arus mainstream),Syī'ah (simpatisan 'Alī), dan kelompok yang tidak mengambil sikap terhadap dua arus mainstream di atas (yang akan menghasilkan

${ }^{5}$ Abū al-Qāsim al-Lālakā’̄, Syarh I'tiqād Ahl al-Sunnah Wa al-Jamā'ah (Mekah: Dār Ṭayyibah, 2003), h. 52., Jalāl al-Dīn al-Suyūtī, al-Jāmi ‘ al-Saghīr (Beirut: Dār al-Fikr, t.t), Jld. 2, h. 15., Abū Nu'aym al-Aṣbihān̄i, Hilyat al-Awliyā' Wa Țabaqāt al-Asfiyā' ' (Beirut: Dār al-Kutub al-'Arab̄̄, t.t), Juz. 6, h. 66. 
kelompok Murji'ah dan Sunnī). ${ }^{6}$ Di mulai dengan persoalan politik yang kemudian bertransformasi menjadi persoalan ideologi inilah diskursus kalam mulai menyebar ke seantero penjuru dunia Islam dengan adanya klaim pembenaran (truth claim) dan menganggap kelompok yang lain salah dengan didukung adanya justifikasi (pembenaran) dari al-Qur'an sebagai pembelaan. Pada tahap ini, metodologi yang digunakan dalam diskursus kalam menggunakan pendekatan skripturalis (scriptural approach) dengan didukung kekuatan akal dalam menganalisis dalam usaha mengcounter pendapat lain. Oleh karenanya ilmu kalam dapat didefinisikan, seperti yang dikatakan al-İjī, 'ilmu yaqtadiru ma 'ahu 'alā itsbāt al- 'âqā'id al-dīniyyah bi $\bar{\imath} r a \bar{d}$ al-hujaj wa daf' al-syibah $^{7}$ (ilmu yang memberikan kemampuan untuk membuktikan kebenaran akidah agama dengan menunjukkan hujjah guna melenyapkan keraguan). Senada dengan al-İjī, Aḥmad Fuād al-Ahwān̄̄ — sarjana muslim asal Mesir yang banyak menulis tentang filsafat - mendefinisikan ilmu kalam sebagai rangkaian argumentasi rasional (al-hujjah al'aqliyyah) yang disusun secara sistematik untuk memperkokoh kebenaran akidah agama Islam. ${ }^{8}$ Dari definisi yang dikemukakan di atas dapat ditarik kesimpulan bahwa ilmu kalam adalah disiplin ilmu yang membahas tentang masalah akidah keimanan seseorang dengan menggunakan argumentasi rasional (al-adillah al-'aqliyyah). ${ }^{9} \mathrm{Al}-$ Ghazālī menambahkan bahwa tujuan dari ilmu kalam adalah untuk

${ }^{6}$ Keterangan lebih utuh dalam memahami asal usul kemunculan ilmu kalam dalam Islam, lih. 'Abd al-Qāhir bin Țāhir al-Baghdādī, al-Farq Bayn al-Firāq (Beirut: Dār al-Kutub al-'Ilmiyyah, t.t.)., Muḥammad bin 'Abd al-Karīm alSyahrastān̄̄, Al-Milal wa al-Nihal (Beirut: Dār al-Kutub al-'Ilmiyyah, 2011).,'Alī Muștafā alGhurābī, Tārīkh al-Firaq al-Islāmiyyah Wa Nasy'at 'Ilm al-Kalām 'Ind al-Muslimīn,Kairo: Maktabah Muhammad 'Alī Șabīh wa Awlāduhu, t.t.)., Ibn Hazm, Al-Fașl fì al-Milal wa al-Ahwā' wa al-Nihal (Beirut: Dār al-Ma'rifah, 1983)., 'Abd al-Raḥmān bin Aḥmad al-Ījīi, al-Mawāqif fì 'Ilm al-Kalām (Mekah: Dār al-Bār, t.t.)., Mușțafā' 'Abd al-Rāziq, Tamhīd Li Tārīkh al-Falsafah al-Islāmiyyah (Kairo: Lajnah al-Ta'līf wa al-Tarjamah, 1959).

7 'Abd al-Raḥmān bin Aḥmad al-Ījīi, al-Mawāqif F̄̄ 'Ilm al-Kalām (Mekah: Dār al-Bār, t.t), h. 7.

${ }^{8}$ Ahmad Fuâd al-Ahwânî, Filsafat Islam (Jakarta: Pustaka Firdaus, 2008), h. 17.

9 'Alī Sāmī al-Nasysyār, Nasy'at al-Fikr al-Falsafí (Kairo: Dār al-Ma‘ārif, 1977), Jld. 1, h. 48. 
menjaga akidah ahl al-sunnah (yang benar) dari kekacauan (akidah) ahl albid'ah. ${ }^{10}$

Pada umumnya pembahasan atau masalah pokok yang dikemukakan dalam ilmu kalam -sebagaimana yang dikatakan Muhammad 'Abduh- membahas tentang wujud Allāh, sifat-sifat yang wajib dan boleh bagi-Nya, dan apa yang wajib dinafikan bagi-Nya, juga membahas tentang rasul-rasul-Nya, untuk membuktikan kebenaran tugas kerasulan mereka, dan apa yang wajib ada pada mereka dan apa yang boleh dinisbatkan kepada mereka. ${ }^{11}$ Sebagian yang lain mengemukakan bahwa masalah yang paling urgen dalam ilmu kalam adalah tentang masalah keesaan Tuhan. Di samping itu juga dibahas tentang masalah kerasulan, akal, dan wahyu, alQur'ān, soal mukmin, kafir, dan musyrik, soal hubungan antara khalik dan makhluk-Nya terutama manusia, yaitu menyangkut perbuatan manusia, janji dan ancaman, kemutlakan kehendak dan kekuasaan Tuhan, keadilan Tuhan, perbuatan Tuhan, surga dan neraka, soal taklif dan lain sebagainya. ${ }^{12}$

\section{Dari Dogmatisme ke Dialektisme: Wacana Liberalisme Kalam Dalam Islam}

Dari pernyataan sub bab di atas dapat disimpulkan bahwa pembahasan ilmu kalam mengalami perluasan makna cakupan pembahasan dari sekedar pembahasan wujūd dan maujūd ke taraf yang lebih kompleks dan rumit. Kompleksitas pembahasan kalam ditandai dengan objek kajian yang semakin meluas dan terdapat banyak kelompok yang mewarnai diskursus kalam terutama ketika ada wacana ide liberalisme (al-fikr al-tahrīî̀) dalam Islam yang diusung oleh kelompok Mu'tazilah, terlebih ketika ilmu kalam berdialog dengan cabang keilmuan yang lainnya terutama dalam bidang filsafat Yunani. Berangkat dari proses dialektika di atas, metodologi yang digunakan dalam ilmu kalam lebih terarah,

${ }^{10}$ Muhammad bin Muhammad al-Ghazālī, Iljām al-'Awām 'An 'Ilm alKalām (Beirut: Dār al-Fikr, 1993), h. 33.

${ }^{11}$ Muhammad 'Abduh, Risālat al-Tawhīd (Kairo: Dār al-Manār, 1366 H), h. 7.

${ }^{12}$ Tsuroya Kiswali, al-Juwaini, Peletak Dasar Teologi Rasional dalam Islam (Jakarta: Erlangga, 2005), h. 7. 
terstruktur, dan sistematis sehingga menghasilkan paradigma keilmuan yang baru karena didukung dengan peranti keilmuan filsafat yang menitikberatkan pada daya intelektual. Berikut adalah salah satu cohtoh pergeseran paradigma dan sekaligus bentuk transformasi pemikiran kalam klasik yang masih kental nuansa dogmatisme berubah menjadi wacana kalam yang lebih dialektis-progresif dalam masalah dzat dan sifat Tuhan dan daya manusia.

'Alī Muștafă' al-Ghurābī mencatat bahwa diskursus seputar sifat Tuhan tumbuh dan berkembang di kalangan umat Islam pertama kali dikemukakan oleh al-Ja'd bin Dirham (w.124 H), ${ }^{13}$ Jahm bin Șafwān (w.128 H) ${ }^{14}$ dan Ghaylān al-Dimasyqī (w.105 H). ${ }^{15} \mathrm{Al}-\mathrm{Ja}$ 'd bin Dirham mengatakan bahwa Allāh Swt. tidak boleh disifati dengan suatu sifat yang mana manusia juga mempunyai sifat tersebut seperti berbicara (al-kalām) dan tidak boleh disifati dengan sifat yang

${ }^{13}$ Al-Ja'd bin Dirham adalah orang pertama yang mengatakan tentang kemakhlukan al-Qur'ān. Ia bermukim di Damaskus, tetapi setelah pahamnya tersebut menyebar luas, ia diburu oleh para petinggi Bani Umayyah dan kabur sampai ke Kūfah dan bermukim di dalamnya sampai pahamnya tersebut diadopsi oleh Jahm bin Șafwān. Pada tahun 124 H bertepatan pada hari raya 'Īd al-Aḍhā, gubernur Kūfah Khālid bin Abdillah al-Qasrī membunuh al-Ja'd di Kūfah. Khālid bahkan menyerukan kepada masyarakat Kūfah di dalam khutbahnya supaya masyarakat menyembelih hewan seperti layaknya ia menyembelih (membunuh) alJa'd bin Dirham. Ismā'īl bin 'Umar bin Katsīr, al-Bidāyah Wa al-Nihāyah (Beirut: Maktabah al-Ma‘ārif, t.t), Jld. 9, h. 350., Muhammad bin Ahmad al-Dzahabī, Mīzān al-I'tidāl F̄̄ Naqd al-Rijāl (Beirut: Dār al-Kutub al-'Ilmiyyah, 1995), Jld. 2, h. 125.

${ }^{14}$ Jahm bin Șafwān memiliki kunyah Abū Muharraz budak Bani Rāsib. Ada yang mengatakan ia berasal dari Samarkand ada juga yang mengatakan dari Tirmidz. Ia merupakan murid al-Ja'd bin Dirham. Jahm dikenal sebagai ahli debat yang handal yang selalu mengandalkan kecerdasan akalnya dalam setiap berdebat. Di antara bukti kecerdasannya adalah ketika ia berdebat dengan kelompok Samaniyah dari India. Mereka (Samaniyah) bertanya: kamu percaya Tuhan? Ya. Jawab Jahm. Pernah tahu wujud-Nya? Tidak. Pernah mendengar ucapanNya? Tidak. Pernah mencium bau-Nya? Tidak. Kamu dapati Dia berbentuk materi atau bisa diraba? Tidak juga. Lantas bagaimana kamu tahu Dia Tuhan? Jahm balik bertanya kepada mereka. Kalian percaya di dalam tubuh ada ruh? Ya. Apakah kalian melihatnya? Tidak. Pernah mendengar suaranya? Tidak. Kalian dapati dia berbentuk materi atau bisa diraba? Tidak. Begitu juga Allāh, tidak bisa dilihat mempunyai wajah, suara, mempunyai tempat dan lainnya. 'Alī Mușțafā' al-Ghurābī, Tārīkh alFiraq al-Islāmiyyah Wa Nasy'at 'Ilm al-Kalām 'Ind al-Muslimīn (Kairo: Maktabah Muḥammad 'Alī Șabīh wa Awlāduhu, t.t), h. 22-3.

${ }^{15}$ Nama lengkapnya Ghaylān bin Marwān al-Dimasyqī. Sementara Marwān adalah bekas budak dari 'Utsmān bin 'Affān. Dikisahkan bahwa ia mengisi hariharinya dengan belajar dan hidup dengan zuhud, berdoa kepada Allāh. Ibid., h. 33. 
bertentangan seperti bisu (al-bukm). ${ }^{16}$ Di dalam sejarah umat Islam, ia adalah orang pertama yang mendeklarasikan paham ta'țill al-șifāt (peniadaan sifat bagi Allāh Swt). Sedangkan Jahm bin Șafwān murid dari Ja'd - mengatakan bahwa siapa saja yang menyifati Allāh dengan sesuatu yang Allāh sifatkan dengan diri-Nya sendiri (di dalam al-Qur'ān) dan Nabi-Nya (di dalam Sunnah) termasuk orang kafir dan penganut paham tasybīh (menyerupakan Allāh dengan makhlukNya). ${ }^{17}$ Senada dengan apa yang dikatakan oleh kedua tokoh di atas, Ghaylān al-Dimasyqī juga mengatakan Allāh tidak mempunyai sifat. Apa yang disebut sifat-sifat Allāh tidak lain adalah dzāt itu sendiri (inna al-șifāt 'ain al-dzāt). ${ }^{18}$ Walaupun di antara ketiga tokoh di atas pada dasarnya mempunyai pola pikir yang sama yaitu menegasikan sifat bagi Allāh, namun ada beberapa aspek perbedaan menyangkut pondasi yang mereka bentuk untuk menegasikan sifat.

Al-Ja'd bin Dirham dan Jahm bin Șafwān mendasarkan pandangan tentang penegasian sifat atas dasar penegasian menyamakan (tasybīh) Allāh dengan makhluk-Nya. ${ }^{19}$ Mereka menghendaki menyucikan (tanzīh) dzāt Allāh dari hal-hal yang tidak patut dan layak disematkan kepada dzāt-Nya yang Suci nan Agung. Seandainya dikatakan bahwa Allāh mempunyai sifat layaknya manusia seperti berbicara (al-kalām), melihat (al-bașar), berkuasa (al-qudrah), murka (al-ghadab) dan sebagainya, maka sesungguhnya kita telah menyamakan Allāh dengan makhluk-Nya. Al-Ja'd dan Jahm bin Șafwān mendasarkan pandangan tentang penegasian sifat (nafy al-șifat) berdasarkan ayat al-Qur'ān laysta kamitslihi syay' (tidak ada sesuatupun yang menyerupai Allāh). Maksud dari ayat di atas adalah bahwa Allāh tidaklah serupa dengan sesuatu apapun dari makhluk-Nya di alam ini. Allāh tidak mempunyai sifat kalam dan tidak disifati dengan sesuatu sifat apapun, Allāh tidak dapat diketahui dengan sesuatu sifat atau perbuatan dan tidak bisa diketahui oleh akal. Yang dimaksud mengetahui, mendengar, melihat, berkuasa - yang terdapat di dalam al-Qur'ān — tak lain adalah dzāt Allāh itu sendiri.

\footnotetext{
${ }^{16}$ Ibid., h. 29.

${ }^{17}$ Ibid., h. 24.

${ }^{18}$ Ibid., h. 34.

${ }^{19}$ Ibid., h. 95.
} 
Selain itu, Allāh tidak boleh disifati dengan dua sifat yang saling bertentangan, Dia tidak berada di atas atau di bawah, tidak pula mempunyai sisi dan arah, tidak di kanan dan di kiri, tidak ringan dan berat. Allāh tidak mempunyai warna dan tubuh (jism), tidak pula dapat dipegang dan dipikirkan. Segala hal yang terlintas di dalam hati bahwa Allāh menyerupai sesuatu, maka sesungguhnya Dia tidaklah demikian. $^{20}$

Ada dua sifat yang dikecualikan oleh al-Ja'd dan Șafwān yang dapat disematkan kepada Allāh yaitu sifat menciptakan (al-khalq) dan sifat membuat ( $a l-f i l)$. Kedua sifat tersebut merupakan sifat yang khusus dimiliki oleh Allāh yang tidak dimiliki oleh makhluk selainNya. Tidak ada pencipta atau pembuat sesuatu di alam ini selain Allāh Swt. Atas dasar ini pula mereka mengatakan bahwa segala perbuatan manusia pada hakikatnya adalah dipaksa oleh Allāh. Penisbatan kata 'berbuat' bagi manusia hanya sebatas makna kiasan

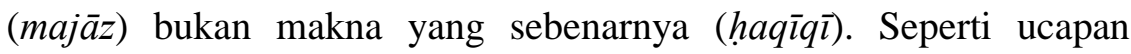
tanaman itu menjadi hijau, hujan itu turun dan siang itu terang. ${ }^{21}$ Kalau al-Ja“d dan Jahm bin Șafwān menegasikan semua sifat kecuali sifat menciptakan (al-khalq) dan sifat membuat (al-fi 'l), Ghaylān alDimasyqī menegasikan semua sifat tanpa ada pengecualian. Oleh karena itu dia menegasikan sifat seperti sifat mengetahui (al-'ilm), berkuasa (al-qudrah), dan berkehendak (al-irādah). Semua sifat tersebut tidak lain adalah dzāt itu sendiri. Atas dasar ini pula kelompok Asy'ariyah menyebutnya sebagai kelompok mu'attilah. ${ }^{22}$ Doktrin penegasian sifat yang dibawa oleh ketiga tokoh di atas ini kemudian diadopsi oleh syaykhal-mu 'tazilah Wāṣil bin 'Ațā' (w. 131 H) sebagai pondasi awal dalam membentuk doktrin tentang nafy alșifat sebagai basis mentauhidkan Allāh. Wāṣil bin 'Ațā' mengatakan tentang nafy al-sifat bahwa apa-apa yang disebut sifat Tuhan sebenarnya bukanlah sifat yang mempunyai wujud tersendiri di luar dzāt Tuhan, tetapi sifat yang merupakan esensi Tuhan. ${ }^{23}$ Karena kalau dikatakan sifat mempunyai wujud tersendiri di luar dzāt Tuhan akan berimplikasi pada adanya yang qadìm selain dzāt Tuhan. Inilah yang

${ }^{20}$ Ibid., h. 25.

${ }^{21}$ Ibid., h. 95.

${ }^{22}$ Ibid., h. 34.

${ }^{23}$ Harun Nasution, Teologi Islam: Aliran-Aliran, Sejarah Analisa Perbandingan (Jakarta: UIPress, 2013), h. 45. 
disebut dengan terbilangnya dzāt yang qadìm (ta 'addud al-qudamā'). Paham seperti ini tentu saja ditolak oleh Wāșil karena menjurus pada sikap menduakan Allāh (syirik) dan pelakunya dicap sebagai kafir. ${ }^{24}$

Diskursus kalam klasik yang akan penulis paparkan selanjutnya adalah tentang daya yang terdapat pada manusia yang akan dikemukakan oleh Abū Ḥan̄ifah. Penulis akan menunjukkan bahwa pergeseran paradigma kalam klasik abad pertama hijriyah berbeda dan nampak jelas dengan abad selanjutnya terutama setelah Nabi Saw. wafat yaitu lebih bersifat dialektis dengan pembahasan yang cenderung lebih liberal-progresif yang tidak ditemukan pada fase awal.

Abū Ḥan̄ifah memandang bahwa manusia tidaklah dipaksa (majbūr) oleh kehendak mutlak Tuhan dalam melakukan perbuatanperbuatannya sebagaimana dikatakan oleh Jahm bin -Șafwān. ${ }^{25}$ Manusia menurutnya memiliki daya perolehan (kasb) untuk melakukan perbuatanperbuatannya. ${ }^{26}$ Ia mengatakan teori kasb di dalam al-Fiqh al-Akbar sebagai berikut:

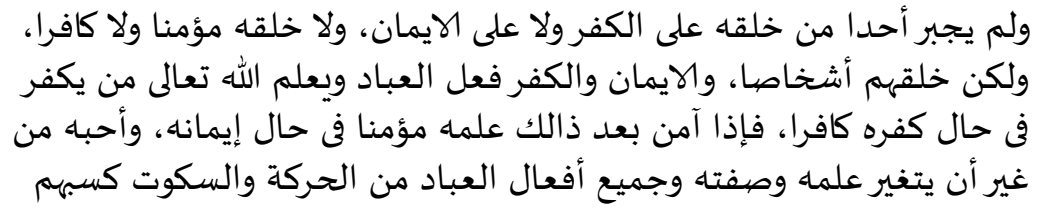

${ }^{24}$ Al-Ghurābī, Tārīkh al-Firaq al-Islāmiyyah, h. 95-6., klaim 'kafir' yang dikemukakan oleh Wāṣil di atas tidak terlepas dari konsepsinya tentang sifat Tuhan. Menurutnya jika konsepsi tentang sifat adalah sebagai sesuatu yang berdiri di luar dzāt-Nya (secara mandiri), maka secara rasio tidak dapat dibenarkan karena akan memberikan pengertian banyak yang qadìm. Pernyataan seperti itu yang menurut Wāṣil dicap sebagai kafir. Berbeda dengan Abū Ḥanīfah dan para pengikutnya yang menganggap sifat Tuhan sebagai sesuatu yang berdiri pada dzāt-Nya sehingga keqadiman di antara keduanya berbeda secara esensial dan tidak menyebabkan banyak yang qadīm. ${ }^{25} \mathrm{Al}$-Ghurābī, Tārīkh al-Firaq al-Islāmiyyah, h. 21.

${ }_{25}^{25}$ Al-Ghurābī, Tārīkh al-Firaq al-Islāmiyyah, h. 21.

${ }^{26}$ Teori kasb yang digadang-gadang merupakan rumusan asli dari Abū Hasan al-Asy'arī (w.324 H) sebenarnya kurang tepat penisbatannya. Karena teori ini sudah dicetuskan oleh para pemikir kalam bahkan jauh sebelum al-Asy'arī. Ḥasan al-Bașrī $($ w.110 H) juga pernah menyebut teori kasb walaupun belum cukup matang dalam sistem pemikirannya. Baru kemudian teori ini dikembangkan dan disempurnakan oleh Abū Hanīfah (w.150 H) untuk membantah pandangan kelompok Jabariyyah yang dimotori oleh Jahm bin Șafwān. Jika demikian adanya maka pencetus teori kasb yang pertama adalah Abū Hanīfah. Al-Nasysyār, Nasy'at al-Fikr al-Falsafì, Jld. 1, h. 239. 


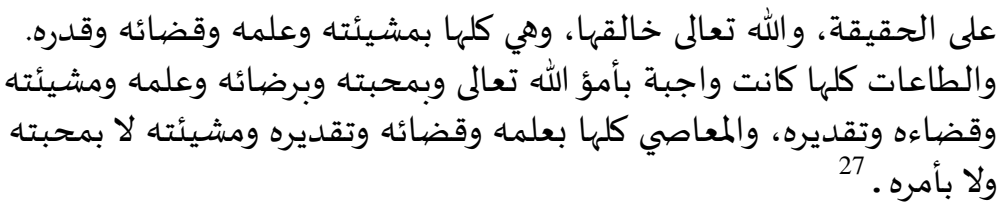

Artinta: Seorang dari makhluk-Nya tidak dipaksa menjadi kafir dan beriman. Tidak pula diciptakan beriman dan kafir akan tetapi diciptakan sebagai individu-individu (yang suci). Sementara iman dan kafir adalah usaha seorang hamba. Allāh mengetahui seorang kafir pada saat dia kafir. Ketika dia beriman setelah kafir maka Allāh mengetahui dia mukmin disaat dia beriman. Allāh mencintainya tanpa berubah ilmu dan sifat-Nya. Semua perbuatan hamba berupa gerak dan diam pada hakikatnya merekalah yang melakukan tetapi Allāh yang menciptakan. Semuanya atas kehendak, ilmu, qaḍà, dan qadar-Nya. Ketaatan itu wajib berdasarkan perintah, cinta, riḍa, ilmu, kehendak, qaḍa', dan qadarNya. Sedangkan kemaksiatan atas ilmu, qad̄à', qadar, dan kehendak-Nya, tetapi bukan berdasarkan cinta, rida dan perintah-Nya.

Dari ucapan di atas ada dua poin penting terkait dengan konsepsi Abū Ḥan̄ifah tentang teori kasb. Pertama, segala perbuatan dan aktivitas yang dilakukan oleh manusia di dunia ini adalah ciptaan Allāh yang diupayakan oleh manusia. Hal ini menjadikan manusia mempunyai daya untuk mewujudkan segala perbuatan-perbuatannya termasuk iman dan kafir. Dari poin pertama Abū Ḥanīfah menyebut ada dua perbuatan yaitu perbuatan Tuhan dan perbuatan manusia. Perbuatan Tuhan mengambil bentuk penciptaan daya dalam diri manusia dan pemakaian daya itu sendiri merupakan perbuatan manusia. Dalam kaitannya dengan permasalahan ini adalah bahwa untuk terwujudnya suatu perbuatan diperlukan kehendak baru terealisasi perbuatan tersebut. Lantas yang menjadi pertanyaan kehendak siapakah ini, Tuhan atau manusia? Jelas menurutnya adalah kehendak Tuhan. Di lain sisi daya yang diciptakan oleh Tuhan dalam konsepsi kasb Abū Ḥan̄̄ah apakah daya Tuhan juga atau daya manusia? Karena orang tidak dapat memandang sesuatu perbuatan

27 'Alī al-Qārī, Syarh al-Fiqh al-Akbar Li al-Imām Abī Hanīfah (Beirut: Dār al-Kutub al-'Ilmiyyah, 1984), h. 77-84 
sebagai perbuatannya sendiri kalau bukan ia sendiri yang mewujudkan perbuatan itu maka daya tersebut mesti daya manusia itu sendiri. ${ }^{28}$

Oleh karena itu menurut Abū Ḥanīfah daya untuk mewujudkan suatu perbuatan berjalan beriringan ketika manusia melakukan suatu perbuatan yang bersangkutan. Karena kalau tidak, maka ada dua kemungkinan; daya ada pada diri manusia sebelum melakukan perbuatan atau daya ada pada diri manusia setelah melakukan perbuatan. Menurut Abū Hanīfah kedua kemungkinan tersebut mustahil adanya. ${ }^{29}$ Dalam hal ini ia mengatakan:

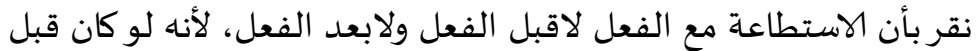

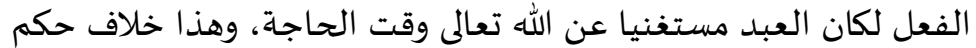

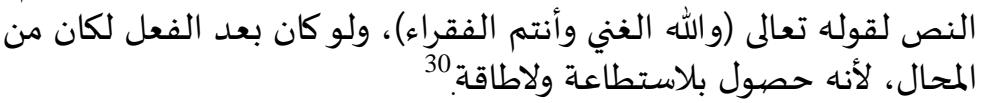

Artinya: Kami meyakini bahwa kemampuan (daya) ada bersamaan dengan perbuatan, bukan sebelum atau sesudah perbuatan. Seandainya (daya) ada sebelum perbuatan maka mesti hamba tidak butuh kepada Allāh dikala ia butuh, tentu ini bertentangan dengan al-Qur'ān. Allāh berfirman; 'Dan Allāh maha kaya sedangkan kalian membutuhkan-Nya'. Selain itu tidak mungkin (daya) ada setelah perbuatan karena perbuatan bisa ada lantaran ada daya dan kekuatan.

Jadi dalam pandangan Abū Ḥan̄ifah perbuatan manusia adalah perbuatannya sendiri (haqīq $\bar{l})$, bukan perbuatan Tuhan yang mewujud pada perbuatan manusia (majāzz). Di dalam kitab al-Fiqh al-Absat, ia mengemukakan argumentasi rasional terkait persoalan di atas sebagai berikut: jika seorang membunuh maka ia akan dibenci oleh

${ }^{28}$ Harun Nasution, Teologi Islam, h. 113.

${ }^{29}$ Pendapat Abū Hanīfah tentang daya yang terdapat pada manusia tidak terlepas dari pernyataan kelompok Mu'tazilah yang berpendapat bahwa manusia adalah pencipta (khāliq) perbuatan-perbuatannya. Jadi menurut mereka daya untuk berbuat terdapat dalam diri manusia sebelum diwujudkannya perbuatan yang bersangkutan.

Pendapat ini jelas ditolak oleh Abū Ḥanīfah karena berimplikasi pada tidak butuhnya manusia kepada Tuhan.

${ }^{30}$ Kamāl al-Dīn Aḥmad bin Husayn al-Bayāḍī. Isyārāt al-Marām Min 'Ibarāt al-Imām Abī Hanīfah alNu'mān Fì Ușūl al-Dīn (Beirut: Dār al-Kutub al'Ilmiyyah, 2007), h. 112. 
masyarakat sedangkan jika tidak membunuh, bahkan sebaliknya (berbuat baik, membebaskan budak, mengasihi dan lain-lain), maka masyarakat akan menyanjungnya. ${ }^{31}$ Seandainya perbuatan manusia adalah perbuatan Tuhan maka konsekuensi logis dari perbuatan tersebut adalah manusia akan bersikap legowo terhadap perbuatan membunuh -yang itu merupakan perbuatan buruk - sebagai perbuatan Tuhan dan tidak mempermasalahkan atau mengambil langkah hukum jika ada seorang yang membunuh orang lain atau bahkan menganggap biasa orang yang membebaskan budak-yang itu merupakan perbuatan mulia - tanpa ada sikap 'kagum' terhadap orang yang melakukan perbuatan baik tersebut. Poin kedua yang dapat diambil kesimpulan dari teori kasb di atas adalah, Tuhan memberikan hukuman kepada manusia berdasarkan perbuatan mereka sendiri yang dilakukan ketika masih hidup di dunia berupa berbuat baik atau buruk.

Satu hal yang perlu dicatat dalam poin ini adalah bahwa persoalan kasb sangat erat kaitannya dengan kehendak Tuhan. Karena dalam pandangan Abū Ḥan̄ifah Tuhan mempunyai kehendak mutlak maka sesungguhnya kehendak manusia adalah kehendak Tuhan. Ini berarti bahwa perbuatan manusia mempunyai wujud atas kehendak Tuhan dan bukan atas kehendak manusia. Hal ini mengandung arti paksaan atau fatalisme. ${ }^{32}$ Ketika manusia melakukan suatu perbuatan baik atau buruk yang itu merupakan atas aktualitas daya yang diciptakan oleh Allāh dalam dirinya dalam arti yang sebenarnya (haqīq $\bar{l}$ ) sehingga berkonsekuensi apa yang yang dilakukan manusia akan dipertanggungjawabkan oleh dirinya sendiri, maka ada permasalahan dilematik paradoksial yang diperhadapkan dalam pemikiran kasb Abū Hanīfah di mana kehendak berbuat baik dan buruk yang sudah diaktualkan secara haqīqi tidak lebih dari kehendak mutlak yang diturunkan Allāh kepada makhluk-Nya. Jika seperti itu apakah pantas bagi Tuhan menghukum hambanya yang melakukan perbuatan buruk dan memberi pahala kepada hambanya yang melakukan perbuatan baik, padahal kedua perbuatan itu berasal dari kehendak mutlak-Nya. Jalan tengah yang dikembangkan dalam

${ }^{31}$ Abū Ḥan̄ifah, al-Fiqh al-Absaṭ (Beirut: Dār al-Kutub al-‘Ilmiyyah, t.t.), h. 55.

${ }^{32}$ Harun Nasution, Teologi Islam, h. 114. 
pemikiran kalam Abū Ḥan̄̄fah dalam menjawab permasalahan di atas adalah dengan dibentuk formulasi atau teori tentang cinta (mahabbah), riḍa (rid̄a ') dan perintah (amr). ${ }^{33}$ Ia mengatakan bahwa manusia melakukan segala perbuatan baik dan buruk atas kehendak Tuhan, tetapi tidak selamanya dengan kerelaan hati Tuhan. Tuhan tidak suka manusia berbuat jahat. Tegasnya manusia berbuat baik atas kehendak Tuhan dan dengan kerelaan hati Tuhan; sebaliknya betul manusia berbuat buruk atas kehendak Tuhan, tetapi tidak atas kerelaan hati Tuhan. ${ }^{34}$ Dari formulasi yang dibentuk oleh Abū Hanīfah dapat ditarik kesimpulan betapa mendalam penguasaannya terhadap isu-isu teologis dengan ditunjang penggunaan nalar yang tajam sehingga tidak mengherankan jika signifikansi pemikiran kalam Abū Ḥan̄fah dalam menjawab berbagai persoalan kalam yang berkembang pada masa silam adalah representatif corak pemikiran rasional awal dalam sejarah perkembangan pemikiran kalam dalam Islam.

Pendapat Abū Hanīfah tentang kasb sebagaimana disebutkan di atas merupakan sintesis dari pendapat Qadariyyah (Mu'tazilah) dan Jabariyyah yang berbeda secara diametral. Kelompok Qadariyyah yang dikemukakan oleh Ma'bad al-Juhanī (w.80 H) mengatakan bahwa manusia berkuasa atas perbuatan-perbuatannya, manusia sendirilah yang melakukan perbuatan-perbuatan baik atas kehendak dan kekuasaannya sendiri dan manusia sendiri pula yang melakukan atau menjauhi perbuatan-perbuatan jahat atas kemauan dan dayanya sendiri. Dalam paham ini manusia merdeka dalam tingkah lakunya. ${ }^{35}$ Sementara pendapat yang berbeda dikemukakan oleh kelompok Jabariyyah yang dipimpin oleh Jahm bin Șafwān. Ia mengatakan bahwa manusia tidak mempunyai daya untuk berbuat sama sekali dan tidak mempunyai pilihan, tidak ada kekuatan untuk berbuat dan semuanya adalah dipaksa. Daya berbuat bagi manusia semuanya merupakan kiasan (majāz) bukan dalam arti sebenarnya (haqīq $\bar{l}$ ) seperti seorang anak tumbuh besar dan rambut memutih. ${ }^{36}$

\footnotetext{
33، Alī al-Qārī, Syarḥ al-Fiqh al-Akbar, h. 77-84.

${ }^{34}$ Harun Nasution, Teologi Islam, h. 114.

${ }^{35}$ Ibid., h. 35.

${ }^{36}$ Akmāl al-Dīn al-Bābartī, Syarh al-Wașiyyah, h. 105.
} 


\section{Pergeseran Paradigma Kalam Klasik Ke Kalam Sosial: Upaya Menggagas Metodologi Kalam Kontemporer}

Pada umumnya pembahasan tentang kajian keagamaan baik itu al-Qur'an, hadis, fikih, akidah, dan sebagainya berdiri sendiri dengan menggunakan metodologi yang diterapkan masing-masing disiplin ilmu tanpa adanya hubungan keterikatan antara satu dengan yang lain. Ketika membahas ilmu-ilmu agama seperti di atas kecenderungan para pengkaji hanya akan membahas hal-hal yang berkaitan dengan tema, subtema, objek kajian, dan domain kajian yang bersangkutan dan tidak akan keluar dari arus tersebut. Setiap kajian hanya akan membahas dan menjawab persoalan yang hanya menjadi wilayah kajian yang bersangkutan. Namun persoalannya adalah apakah jika demikian adanya, ilmu-ilmu agama tidak dapat merespon persoalanpersoalan yang datang dikemudian hari? Dalam artian wilayah kajian ilmu-ilmu keagamaan harus tetap mempertahankan transendensinya tanpa ikut campur dengan persoalan-persoalan profan duniawi yang berkembang pada era kontemporer sekarang? Apakah tidak seharusnya ilmu-ilmu keagamaan ikut campur dengan ilmu-ilmu non agama sehingga harus ditampakkan disparitas antara kedua disiplin ilmu di atas karena perbedaan yang mencolok dalam ranah ontologi, epistemologi, metodologi, dan paradigma yang digunakan?

M. Amin Abdullah mengatakan bahwa keilmuan agama (ușūl $a l-d \bar{i} n$ ) masa depan adalah keilmuan yang terintegrasi-terinterkoneksi dengan disiplin keilmuan yang lain. Keilmuan agama berinteraksi dan berdialog dengan sains, keilmuan sosial dan humaniona. Jika keilmuan agama merasa cukup dengan dirinya sendiri (al-muhāfazah 'alā al-qadìm al-sāalih), tanpa bersentuhan dan bantuan keilmuan yang lainnya (wa al-akhdzu bi al-jadìd al-așlah), maka ia tidak mempunyai masa depan yang dapat diharapkan. ${ }^{37}$ Mengapa harus demikian? Paling tidak apa urgensi mengaitkan kajian keislaman berdialog dengan ilmu yang lainnya sehingga harus disinergikan, diintegrasikan, dan diinterkoneksikan? Paling tidak alasan yang cukup memadai untuk menjawab hal di atas terdapat dalam problem

37 M. Amin Abdullah, 'Fikih dan Kalam Sosial Era Kontemporer; Perjumpaan Ulūm al-Dīn dan Sains Modern Menuju Fresh Ijtihad', dalam Akhmad Sahal dan Munawir Aziz (ed.), Islam Nusantara; Dari Ushūl Fikih Hingga Paham Kebebasan (Bandung: Mizan, 2015), h. 69. 
yang ada di dalam tubuh Islam sendiri yang meliputi ciri fundamentalisme budaya Islam akan ketergantungan yang sangat kuat terhadap nas atau teks (dalam bahasa M. Amin Abdullah kebudayaan teks [hadarat al-naș]). ${ }^{38}$ Kaitannya dengan pembahasan kalam klasik dalam permasalahan dengan hal-hal yang bersifat spekulatif seperti dzat dan sifat Tuhan, kalamullah, paham tasybīh (menyerupakan Allah dengan makhluk) dan ta'țil (penegasian sifat Allah), kemampuan akal, daya manusia, dan lainnya selalu dan harus menyertakan landasan normatif dari teks al-Qur'an dan hadis. Argumentasi yang dibangun dalam mengcounter pendapat kelompok lain harus didasarkan landasan normatif yang jelas, jika tidak demikian maka semua bangunan argumentatif akan runtuh dan mudah patah bahkan akan ditolak (mardūd). Apakah persoalan di atas akan tetap relevan dengan dunia yang sudah berubah, terlebih harus dihadapkan dengan berbagai disiplin ilmu sains dan sosial yang mendominasi stuktur bangunan keilmuan dunia? Maka perlu diingat bahwa agama tidak hanya terkait dengan keyakinan (akidah) dan ritual (ibadah) semata. Agama juga terkait dengan persoalanpersoalan lain seperti kepemimpinan (leadership) yang bersentuhan dengan sistem kenegaraan dan kepemerintahan, sistem moral (morality) termasuk tata pergaulan antara sesama manusia di luar kelompok agamanya, kelembagaan (institution) sosial, pendidikan, ekonomi, belum lagi yang terkait dengan alat-alat, simbol-simbol yang dipergunakan dan seni (art dan tools). Dalam wilayah kelompok yang terakhir ini (leadership, morality, institution dan art) agak sulit jika semuanya harus berlandaskan dengan nas atau teks. ${ }^{39}$

Dalam bahasa agama Islam biasa dikenal istilah al-nușūs mutanāhiyah wa al-waqā' 'i ghayr mutanāhiyah (teks itu terbatas sedangkan peristiwa-peristiwa sejarah kemanusiaan tidaklah terbatas). Kelompok yang terakhir ini terkena hukum perubahan sejarah, karena budaya dan peradaban umat manusia (human experience) terus berkembang sesuai dengan sejarah dan perkembangan ilmu pengetahuan, pertemuan dan kontak budaya dengan bangsabangsa lain, perkembangan sains dan teknologi, dan

${ }^{38}$ M. Amin Abdullah, Islamic Studies di Perguruan Tinggi; Pendekatan Integratif-Interkonektif (Yogyakarta: Pustaka Pelajar, 2006), h. 57.

${ }^{39}$ M. Amin Abdullah, 'Fikih dan Kalam Sosial Era Kontemporer..., h. 72. 
begitu seterusnya. Dalam konteks seperti ini sudah seharusnya kajian kalam, terutama para pengkaji yang concern dengan masalah kalam, harus merumuskan bagaimana menghubungkan dan mendialogkan antara yang diyakini atau dianggap sebagai hal-hal yang tetap (altsawābit) dan wilayah yang berubah-ubah (almutaghayyirah). Dari sini kemudian dapat berkembang istilah-istilah baru yang belum atau tidak begitu dikenal di era kalam klasik seperti pembedaan antara wahyu dan pemahaman atau penafsiran terhadap wahyu (Abdul Karim Sorous), asbāb al-nuzūl makro dan mikro (double movement) (Fazlur Rahman), al-ma'na (pencarian makna asli) danal-maghza atau signifikansi (pencarian makna saat ini) (Nasr Hamid Abu Zaid), antara asbāb al-nuzūl qadīm (pemahaman makna asbāb al-nuzūl era klasik) dan asbāb al-nuzūl jadìd (pemahaman makna asbāb al-nuzūl era modern dan masa kini) (Abdullah Saeed), dan begitu seterusnya. ${ }^{40}$

Kalam sosial pada dasarnya adalah persoalan bagaimana manusia Muslim yang hidup di era kontemporer sekarang ini memecahkan persoalan keterhubungan, keterpisahan, keterkaitan dan dialektika antara teks dan realitas (min al-naș ilā al-wāqi ). Tatanan sosial, politik, ekonomi, budaya, ilmu pengetahuan yang berubah, berbeda, dan berkembang secara radikal dari tatanan sosial, politik, ekonomi, budaya, seni dan ilmu pengetahuan era klasik-skolastik adalah bagian dari problem ijtihad kontemporer. Diperlukan ijtihad kontemporer, bahkan ijtihad yang segar (fresh ijtihad), untuk membahas keberagamaan manusia Muslim era baru sekarang. Keterkaitan, keterhubungan, dan perbedaan dan keterpisahan antara nas dan penafsiran terhadap nas dalam setiap periode zaman yang dilalui oleh sejarah kebudayaan Islam (klasik, tengah, modern, posmodern) adalah tema sentral pembahasan kalam sosial. ${ }^{41}$ Statement di atas memberikan gambaran kepada para kalangan baik itu dari akademisi, peneliti, atau masyarakat umum yang interest dengan kajian kalam akan keniscayaan adanya pembaruan (tajdīd) yang bersifat mendesak (darūrah) untuk mengembangkan arah kajian ilmu kalam di masa yang akan datang atau era kontemporer. Pertama, pembaruan dalam metodologi yang diterapkan dalam ilmu kalam dan beberapa aspek objek kajian yang bisa disandarkan dalam pembahasan ilmu kalam. Kedua, pembaruan dengan cara

\footnotetext{
${ }^{40}$ M. Amin Abdullah, 'Fikih dan Kalam Sosial Era Kontemporer..., h. 73.
} 
memasukkan masalah-masalah kontemporer (mu'āṣir) dalam pembahasan ilmu kalam yang sulit dicarikan jalan keluar, terutama dalam masalah-masalah yang tidak bisa dijawab kecuali dengan menggunakan analisis dan metodologi yang diterapkan di dalam ilmu kalam. ${ }^{41}$

Masalah-masalah yang termasuk dalam kajian kalam sosial era kontemporer di antaranya, pertama masalah Islam dan kebebasan yang berkaitan dengan adanya prinsip persamaan dalam aspek perbuatan dan pemikiran. Kedua, masalah Islam dan keadilan ('adālah) yang di dalamnya membahas tentang reinterpretasi makna keadilan dan persamaan antar manusia dalam berbagai aspek. Ketiga, masalah hak-hak manusia yang berkaitan dengan hubungan antara agama dan hak-hak manusia, sejauh mana hak-hak manusia tersebut dan bagaimana pengertian dalam ranah yang lebih global. Keempat, masalah yang berkaitan dengan perempuan yang bisa mencakup persamaaan dan keadilan bagi seorang perempuan dan bagaimana keadilan tersebut terbentuk. Kelima, permasalahan-permasalahan yang berkaitan dengan persoalan filsafat dan permasalahan kontemporer yang dibahas oleh kalangan orientalisme, dan lain-lain. Jangan dikira bahwa permasalahan-permasalahan di atas bukan merupakan permasalahan yang selayaknya tidak dibahas dalam disiplin ilmu kalam dan menganggapnya hal yang asing ( gharìb) atau akan mengubah obyek kajian yang tidak pernah dibahas dalam permasalahan kalam oleh para ulama terdahulu. Semua bentuk dan pengembangan permasalahan di atas, atau mungkin masih banyak permasalahan yang perlu dimasukkan ke dalam ranah pembahasan kalam sosial kontemporer, masih dalam cakupan wilayah ilmu kalam dilihat dari sisi persamaan metodologi yang digunakan dalam ilmu kalam. Bahkan jika kita melihat pada zaman terdahulu, akan ditemukan preseden untuk menjustifikasi pembahasan di atas ke dalam ranah ilmu kalam, ketika para ahli kalam (mutakallimūn) memasukkan pembahasan tentang masalah membersihkan sepatu (mash 'alā al-khuffayn) dan imamah di mana kedua masalah di atas

${ }^{41} \mathrm{Sa}$ ‘īd 'Abd al-Lațîf Foudah, Mawqīf al-Imām al-Ghazālī Min 'Ilm alKalām (Beirut: Dār al-Fatḥ, 2009), h. 44. 
termasuk dalam kategori masalah furū'iyyah, bukan masalah i'tiqādiyyah. ${ }^{42}$

\section{E. Penutup}

Bangunan epistemologi dan metodologi yang digunakan dalam diskursus kalam klasik yang cenderung bersifat skripturalis dan atomistik an sich dengan memfokuskan pada dialektisme skriptural sebagai basis utama dengan ditopang argumentasi rasional (al-hujjah al'aqliyyah) yang tidak mengindahkan kehidupan nyata (wāqi', realistis) sudah selayaknya merubah paradigma berpikir supaya dapat menjawab berbagai tantangan keilmuan yang kian global seperti sekarang ini. Transformasi paradigma keilmuan kalam klasik yang bersifat spekulatif harus mendialogkan dengan disiplin keilmuan seperti sains, sosial, budaya dan lainnya. Oleh karenanya, basis pembentuk keilmuan kalam klasik memerlukan seperangkat keilmuan yang lain, selain yang diambil dari fikih, usul fikih, dan qawā'id alfiqhiyyah, dengan menggunakan dan mencangkok beberapa disiplin ilmu khususnya sains, ilmu sosial dan humaniora kontemporer. Pembahasan kalam sosial/modern tidak selalu sama dengan wacana yang ditelurkan kalam klasik namun harus ada penambahan, perluasan objek kajian, progresifitas berpikir, inovasi, rekonstruksi, dialogisasi, integrasi yang semuanya menunjukkan akan pentingnya pergeseran paradigma yang lebih membumi dan dapat menyesuaikan dengan disiplin keilmuan profan lainnya tanpa ada sikap tabu, alergi dan antipati terhadap disiplin keilmuan di luar diri (eksternal) kajian kalam klasik. []

${ }^{42} \mathrm{Sa}$ ‘īd 'Abd al-Lațîf Foudah, Mawqīf al-Imām al-Ghazālī Min 'Ilm alKalām, h. 45. 


\section{DAFTAR PUSTAKA}

Abduh, Muḥammad, Risālat al-Tawḥ̄d, Kairo: Dār al-Manār, 1366 $\mathrm{H}$.

Abdullah, M. Amin, 'Fikih dan Kalam Sosial Era Kontemporer; Perjumpaan Ulūm al-Dīn dan Sains Modern Menuju Fresh Ijtihad', dalam Akhmad Sahal danMunawir Aziz (ed.), Islam Nusantara; Dari Ushūl Fikih Hingga Paham Kebebasan, Bandung: Mizan, 2015.

, Islamic Studies di Perguruan Tinggi; Pendekatan Integratif-Interkonektif, Yogyakarta: Pustaka Pelajar, 2006.

Abū Ḥan̄fah, al-Fiqh al-Absat, Beirut: Dār al-Kutub al-'Ilmiyyah, t.t. Al-Ahwān̄̄, Aḥmad Fuād, Filsafat Islam, Jakarta: Pustaka Firdaus, 2008.

Anīs, Ibrāhim, dkk, al-Mu jam al-Wasīt, Kairo: Majma‘ al-Lughah al-'Arabiyyah, t.t.

Al-Aṣbihān̄̄, Abū Nu'aym, Hilyat al-Awliyā' Wa Tabaqāt al-Așfiyā', Beirut: Dār al-Kutub al'Arabī, t.t.

Al-Baghdādī, 'Abd al-Qāhir bin Țāhir, al-Farq Bayn al-Firāq, Beirut: Dār al-Kutub al'Ilmiyyah, t.t.

Bayāọ̄ī, Kamāl al-Dīn Aḥmad bin Ḥusayn. Isyārāt al-Marām Min 'Ibarāt al-Imām Ab̄̄ Hanīfah al-Nu'mān Fì Ușūl al-Dīn, Beirut: Dār al-Kutub al-'Ilmiyyah, 2007.

Al-Dzahabī, Muḥammad bin Aḥmad, Mīzān al-I'tidāl F̄̄ Naqd alRijāl, Beirut: Dār al-Kutub al-'Ilmiyyah, 1995.

Foudah, Sa'īd 'Abd al-Lațị̂, Mawqĩf al-Imām al-Ghazālì Min 'Ilm alKalām, Beirut: Dār alFatḥ, 2009.

Al-Ghazālī, Muḥammad bin Muḥammad, Iljām al-'Awām 'An 'Ilm al-Kalām, Beirut: Dār alFikr, 1993.

Al-Ghurābī, 'Alī Muștafā, Tārīkh al-Firaq al-Islāmiyyah Wa Nasy'at 'Ilm al-Kalām 'Ind alMuslimīn, Kairo: Maktabah Muhammad 'Alī Ṣabīh wa Awlāduhu, t.t.

Ibn Ḥazm, Al-Faṣl fì al-Milal wa al-Ahwā' wa al-Nihal, Beirut: Dār al-Ma'rifah, 1983. Ibn Katsīr, Ismā'īl bin 'Umar, al-Bidāyah Wa al-Nihāyah, Beirut: Maktabah al-Ma'ārif, t.t. Ibn Manẓūr, 
Muhammad bin Mukrim, Lisān al-'Arab, Beirut: Dār alȘādir, t.t.

Al-İj̄̄, 'Abd al-Raḥmān bin Aḥmad, al-Mawāqif fì 'Ilm al-Kalām, Mekah: Dār al-Bār, t.t.

Kiswali, Tsuroya, al-Juwaini, Peletak Dasar Teologi Rasional dalam Islam, Jakarta: Erlangga, 2005.

Al-Lālakā'̄i, Abū al-Qāsim, Syarh I'tiqād Ahl al-Sunnah Wa alJamā'ah, Mekah: Dār Țayyibah, 2003.

Nasution, Harun, Teologi Islam: Aliran-Aliran, Sejarah Analisa Perbandingan, Jakarta: UIPress, 2013.

Al-Nasysyār, 'Alī Sāmī, Nasy'at al-Fikr al-Falsafí, Kairo: Dār alMa‘ārif, 1977.

Al-Qārī, 'Alī, Syarh al-Fiqh al-Akbar Li al-Imām Abì Hanīfah, Beirut: Dār al-Kutub al'Ilmiyyah, 1984.

Al-Rāzī, Muḥammad bin Ab̄̄ Bakr, Mukhtār al-Ṣihhậ̣h, Beirut: Dār al-Fikr, 2009.

Al-Rāziq, Muștafā' 'Abd, Tamhīd Li Tārīkh al-Falsafah alIslāmiyyah, Kairo: Lajnah al-Ta' līf wa al-Tarjamah, 1959.

Al-Ṣābūnī, 'Alī, Șafwat al-Tafāsīr, Kairo: Dār al- Șābūnī, 1997.

Al-Suyūtī, Jalāl al-Dīn, al-Jāmi ' al-Ṣaghìr, Beirut: Dār al-Fikr, t.t.

Al-Syahrastān̄̄, Muhammad bin 'Abd al-Karīm, Al-Milal wa alNihal, Beirut: Dār al-Kutub al-'Ilmiyyah, 2011.

Syaltūt, Mạ̣mūd, al-Islām Wa al-Syarī'ah, Kairo: Dār al-Qalam, 1966. 